\title{
コンクリートの欠陷部に生じる 中性化による鉄筋腐食の形態と速度
}

\section{大 即 信 明*宮里 心 - * 木 村勇 人** \\ Corrosion Cell Formation Pattern and Rate of Steel Corrosion Induced by Carbonation in Concrete with Defects}

by

\author{
Nobuaki Otsuki ${ }^{*}$, Shin-ichi Mivazato * and Hayato KimurA ${ }^{* *}$
}

The objective of this study was to analyze comprehensively the corrosion cell formation pattern (macro-cell and micro-cell) and the corrosion rate induced by carbonation in concrete with joints or cracks. First, mortar tests were performed using specimens with model defects that simulated cold joints or bending cracks. Herein three important factors that caused steel corrosion were investigated in detail. These factors were : 1) carbonized location, 2) supply of water and oxygen, and 3) water-cement ratio of mortar. Next, concrete tests were performed using specimens with cold joints and bending cracks. The results obtained in this study were as follows ; a) 27 cases of which the carbonized location, supply of water and oxygen, and the water-cement ratio of mortar differed were experimented. As results, the corrosion cell formation pattern and the corrosion rate were comprehensively analyzed based on unified conditions. b) In the case of carbonation-induced corrosion with defects, macro-cell corrosion would be formed regardless of the water-cement ratio. Also, the corrosion rate decreased with the decreasing of water-cement ratio. c) The result b) was confirmed not only in mortar tests but also in concrete tests. d) According to above results, it could be said that the low water cement ratio was excellent in the durability for the steel corrosion, when concrete with defects received the influence of carbonation.

Key words : Carbonation-induced corrosion, Defects, Macro-cell, Micro-cell, Corrosion rate

\section{1 序論 \\ $1 \cdot 1$ 背景 \\ コンクリート内部の鉄筋は高アルカリ環境下にあるた} め，鉄筋表面には不動態皮膜が形成され，腐食から保護 されている。しかしながら，二酸化炭素の浸透によりコ ンクリートが中性化した場合, 内部鉄筋の腐食は誘発さ れる．特に，コールドジョイントや曲げひび割れなどの 欠陷部では，腐食要因物質の二酸化炭素，水分や酸素が 局所的に多量に侵入する。これに伴い，早期に腐食が発 生し，さらに増進することになる。また，その腐食性状 は欠陥部の種類や外部環境, コンクリートの水セメント 比によって変化すると考えられる，したがって，欠陷部 を有する鉄筋コンクリート部材に生じる中性化による腐 食が, どのような腐食形態（マクロセル腐食, ミクロセ

Table I . Physical property and chemical analysis of cement.

\begin{tabular}{|c|c|c|c|c|}
\hline \multicolumn{3}{|c|}{ Physical tests } & \multicolumn{2}{|c|}{ Chemical analysis $(\%)$} \\
\hline \multicolumn{2}{|c|}{$\operatorname{Density}\left(\mathrm{g} / \mathrm{cm}^{3}\right)$} & 3.16 & $\mathrm{MnO}$ & 1.6 \\
\hline \multicolumn{2}{|c|}{$\begin{array}{c}\text { Blaine } \\
\text { Fineness }\left(\mathrm{cm}^{2} / \mathrm{g}\right)\end{array}$} & 3270 & $\mathrm{SO}_{3}$ & 1.9 \\
\hline \multirow{2}{*}{$\begin{array}{c}\text { Setting } \\
\text { time (min) }\end{array}$} & initial & 155 & Ig. Loss & 1.4 \\
\hline & final & 229 & Alkalis as $\mathrm{Na}_{2} \mathrm{O}$ & 0.62 \\
\hline \multicolumn{2}{|c|}{$\begin{array}{c}\text { Compressive } \\
\text { Strength(MPa) }\end{array}$} & $\begin{array}{c}60.2 \\
\text { (28day) }\end{array}$ & $\mathrm{Cl}$ & 0.006 \\
\hline
\end{tabular}

ル腐食）で，かつどれだけの腐食速度かを詳細に検討し 整理する必要がある。

これまでも，你を考慮しない鉄筋コンクリート部材 に対する中性化腐食を検討した研究はある.例えば1), 2), 3) し かしながら，実構造物で散見される打継目やひび割れ等 の欠陥の影響を考慮し, 腐食形態および腐食速度に関し て統一した基準でかつ網羅的に整理・比較した研究は著 者らの知る限りない.

\section{$1 \cdot 2$ 目的}

以上の背景から，本研究では，1) モデル欠陷部に生じ る中性化による腐食の形態と速度を, 統一した基準で網 羅的に整理する，2) 中性化の影響を受ける鉄筋コンクリ 一ト部材の代表的な欠陷部であるコールドジョイント部 および曲げひび割れ部を対象とし，腐食の形態と速度を 評価する，ことを目的とし実験的検討を行った.

Table II. Physical property of fine Table III . Chemical aggregate.

\begin{tabular}{|c|c|}
\hline Density $\left(\mathrm{g} / \mathrm{cm}^{3}\right)$ & 2.60 \\
\hline $\begin{array}{c}\text { Coefficient of water } \\
\text { absorption }(\%)\end{array}$ & 2.20 \\
\hline Fineness Modulus & 2.59 \\
\hline Max grain size (mm) & 5 \\
\hline
\end{tabular}
analysis of steel.

\begin{tabular}{|c|c|}
\hline $\mathrm{Fe}$ & 99.13 \\
\hline $\mathrm{C}$ & 0.12 \\
\hline $\mathrm{Si}$ & 0.12 \\
\hline $\mathrm{Ma}$ & 0.58 \\
\hline $\mathrm{P}$ & 0.031 \\
\hline $\mathrm{S}$ & 0.023 \\
\hline
\end{tabular}

$\dagger \quad$ 原稿受理 平成 12 年 11 月 1 日 Received Nov. 1, 2000

* 東京工業大学大学院理工学研究科国際開発工学専攻 ₹152-8552 東京都目黒区大岡山, Dept. of International Development Eng., Tokyo Inst. of Tech., Meguro-ku, Tokyo, 152-8552

** 五洋建設㑣) テ980-8605 仙台市青葉区二日町, Penta-Ocean Construction Co., Aoba-ku, Sendai, 980-8605 


\section{2 モルタル試験}

\section{$2 \cdot 1$ 実験概要}

$2 \cdot 1 \cdot 1$ 使用材料 セメントは普通ポルトランドセ メントを使用した。物理的性質および化学成分を Table Iに示す。細骨材は千葉県小櫃産の陸砂を使用した。物 理的性質を Table II に示す．鉄筋は丸鋼 (SR235， $\phi 9$ mm）を使用した。化学成分を Table IIIに示す。混和剤 として,ナフタレンスルホン酸系高性能 $\mathrm{AE}$ 減水剂, 扔 よびメチルセルロース系増粘剛を使用した。

2. $1 \cdot 2$ 供試体概要 供試体概要を Fig. 1 に示す。 鋼材内部を流れる電流を測定するため 9 つ要素に分割 した鉄筋を用いた。鋼材を $5 \mathrm{~mm}, 10 \mathrm{~mm}, 20 \mathrm{~mm}$, $30 \mathrm{~mm}$ に切断し, 紙やすりで黒皮を剥いだ。このうち $5 \mathrm{~mm}, 10 \mathrm{~mm}, 30 \mathrm{~mm}$ の鉄筋要素には両端部, $20 \mathrm{~mm}$ の 鉄筋要素には一方の端部のみリード線をはんだ付けした。 その後, 中央に $5 \mathrm{~mm}$ の鉄筋要素を 3 本配置し, 厹の両
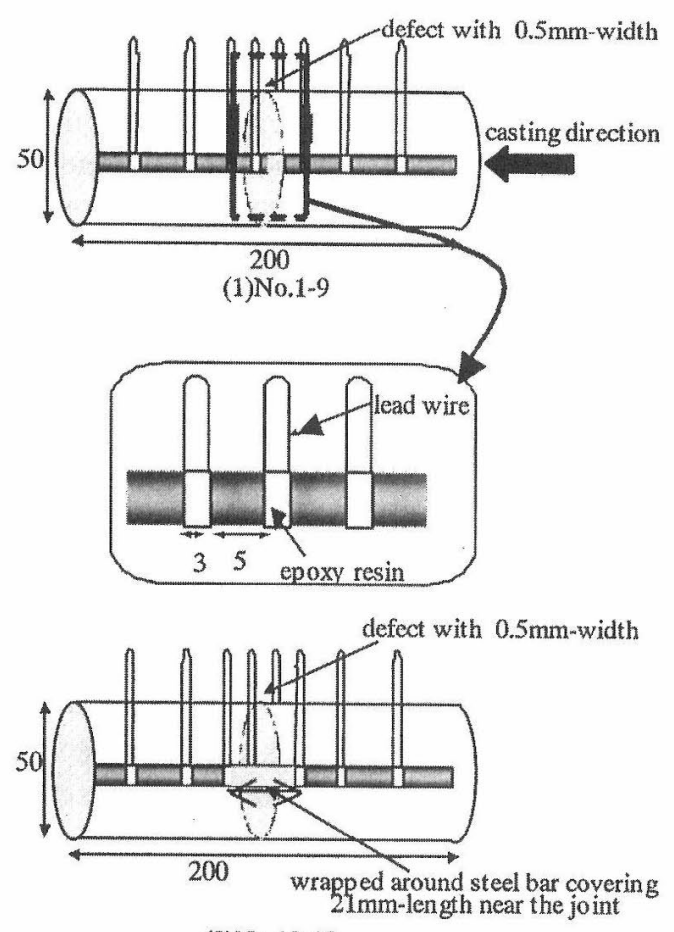

(2) No.10-18

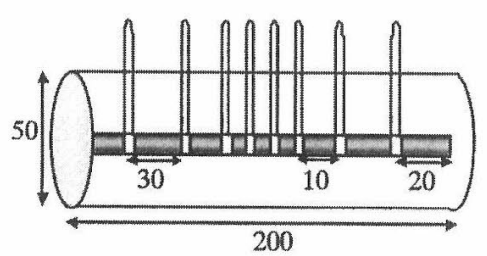

(3) No.19-27

[mm]

Fig. 1. Configuration of specimen (mortar tests).

Table IV. Mixture proportion of mortar.

\begin{tabular}{|c|c|c|c|c|}
\hline \multirow{2}{*}{ w/C } & \multirow{2}{*}{ S/C } & \multicolumn{2}{|c|}{ Agent(C $\times$ wt\%) } & \multirow{2}{*}{$\begin{array}{c}\text { Slump } \\
\text { flow }\end{array}$} \\
\cline { 3 - 4 } & & $\mathrm{A}$ & $\mathrm{B}$ & 170 \\
\hline 0.3 & 2.5 & 2.0 & - & 200 \\
\hline 0.5 & 2.5 & - & - & 260 \\
\hline 0.7 & 2.5 & - & 1.2 & \\
\hline
\end{tabular}

Note) $\mathrm{A}$ : superplasticizer, $\mathrm{B}$ : high velocity agent
端に $10 \mathrm{~mm}$ ，その雨端に $30 \mathrm{~mm}$ ，最端部に $20 \mathrm{~mm}$ の鉄筋 要素が連結するように，各鉄筋要素問をエポキシ樹脂で 絶縁接続した。 その後, 隣接するリード線を接続して電 気的に一本の鋼材とみなせるようにした。なお，陷部 に近い位置の腐食速度を詳細に检討するため，9つの鉄 筋要素のうち中央の鉄筋要素を特に細かく分割した。

打設方法を以下に示す。前処理された鋼材を型枠中心 に配真した。供試体中心に欠陷部を生じさせるため，モ ルタルは 2 層に分けて打設した。はじめに, 直径 $50 \mathrm{~mm}$, 高さ $200 \mathrm{~mm}$ の型枠半分まで打設した。 24 時間後表面の レイタンスを十分に除去し，2層目を打設した。また， 打設の際にNo.1 No.9 供試体 (Table V参照) におい ては，打継面に厚さが $0.5 \mathrm{~mm}$ のろ紙を挟んだ。No.10 No.18 供試体においては, 打継面および打継目を中心に $21 \mathrm{~mm}$ の範囲の鉄筋周囲にろ紙を卷いた。ここで鉄筋周 囲のろ紙は，曲げひび割れ近傍の鉄筋とコンクリートの はく離 ${ }^{4)}$ を模擬するものである. No.19〜 No.27 供試体 においては，二酸化炭素，酸素および水分を内部鉄筋全 体に一様に供給させるため，ろ紙を用いていない。

モルタルの配合を Table IVに示す。砂セメント比は 2.5 とした。また，水セメント比が 0.3 の无ルルには，高 性能 $\mathrm{AE}$ 減水剂をセメントに対して $2.0 \mathrm{wt} \%$ 添加した。一 方，水セメント比が 0.7 のモルルには増粘剤をセメン トに対して $1.2 \mathrm{wt} \%$ 添加した。

養生方法を以下に示す。脱型後全ての供試体は湿潤環 境中にて 4 週間の初期養生を行った。攵の後, 中性化促 進環境下（二酸化炭素濃度 $10 \%$, 温度 $40^{\circ} \mathrm{C}$, 湿度 $70 \%$ ) に暴露した。この暴露期間中において, 同様の条件で作 製・養生された 9 種類（ろ紙の配置 3 水準, 水セメント 比 3 水準) の予備供試体を割裂し, フェノ一ルフタレイ

Table V. The experiment cases (mortar test).

\begin{tabular}{|c|c|c|c|}
\hline No & $\begin{array}{c}\text { Carbonized } \\
\text { Location }\end{array}$ & $\begin{array}{c}\text { supply of } \\
\mathrm{H}_{2} \mathrm{O}, \mathrm{O}_{2}\end{array}$ & $\mathrm{~W} / \mathrm{C}$ \\
\hline 1 & \multirow{9}{*}{ Joint only } & \multirow{3}{*}{ wet } & 0.3 \\
\hline 2 & & & 0.5 \\
\hline 3 & & & 0.7 \\
\hline 4 & & \multirow{3}{*}{$\begin{array}{l}\text { dry \& wet } \\
\text { repetition }\end{array}$} & 0.3 \\
\hline 5 & & & 0.5 \\
\hline 6 & & & 0.7 \\
\hline 7 & & \multirow{3}{*}{ dry } & 0.3 \\
\hline 8 & & & 0.5 \\
\hline 9 & & & 0.7 \\
\hline 10 & \multirow{9}{*}{$\begin{array}{l}\text { Joint and its } \\
\text { surroundings }\end{array}$} & \multirow{3}{*}{ wet } & 0.3 \\
\hline 11 & & & 0.5 \\
\hline 12 & & & 0.7 \\
\hline 13 & & \multirow{3}{*}{$\begin{array}{l}\text { dry \& wet } \\
\text { repetition }\end{array}$} & 0.3 \\
\hline 14 & & & 0.5 \\
\hline 15 & & & 0.7 \\
\hline 16 & & \multirow{3}{*}{ dry } & 0.3 \\
\hline 17 & & & 0.5 \\
\hline 18 & & & 0.7 \\
\hline 19 & \multirow{9}{*}{$\begin{array}{c}\text { the whole } \\
\text { part }\end{array}$} & \multirow{3}{*}{ wet } & 0.3 \\
\hline 20 & & & 0.5 \\
\hline 21 & & & 0.7 \\
\hline 22 & & \multirow{3}{*}{$\begin{array}{l}\text { dry \& wet } \\
\text { repetition }\end{array}$} & 0.3 \\
\hline 23 & & & 0.5 \\
\hline 24 & & & 0.7 \\
\hline 25 & & \multirow{3}{*}{ dry } & 0.3 \\
\hline 26 & & & 0.5 \\
\hline 27 & & & 0.7 \\
\hline
\end{tabular}

Note) At supply of $\mathrm{H}_{2} \mathrm{O}$ and $\mathrm{O}_{2}$, wet means more $\mathrm{H}_{2} \mathrm{O}$ and less $\mathrm{O}_{2}$. Dry means more $\mathrm{O}_{2}$ and less $\mathrm{H}_{2} \mathrm{O}$. Dry and wet repetition means both more $\mathrm{H}_{2} \mathrm{O}$ and $\mathrm{O}_{2}$. 
ンアルコール溶液を噴霧することにより，内部鉄筋近傍 におけるモルタルの中性化進行程度を評価した。これに より，Table Vに示す各位置において鉄筋近傍の.モルタ ルが中性化したことを確認した後, 本試験養生を開始し た。ここで本試験養生とは, Table Vに示す水分および 酸素の供給を行うために実施した湿潤養生（湿度 $90 \%$ 室

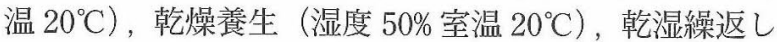
養生（24 時間の湿潤状態と，60 時間の乾燥状態が繰り 返される環境）のことである。なお，全ての供試体にお いて本試験期間は 56 日間である。

$2 \cdot 1 \cdot 3$ 実験ケース 実験ケースを Table Vに示す。 水セメント比は $0.3 ， 0.5,0.7$ の 3 水準とした. 水分・酸 素の供給条件は, 一般の外部環境を考虑し, 水分が多く 酸素が少ない湿潤環境，水分および酸素がともに多い乾 湿繰返し環境, 水分が少なく酸素が多い乾燥環境の 3 水 準とした。また, 中性化位置は欠陮部, 欠陷部と近傍, 全体の 3 水準とした。それぞれを組み合わせた 27 水準 について, 各 2 本の供試体を作製した。

$2 \cdot 1 \cdot 4$ 腐食電流密度の定義および測定方法 本研 究では, 鉄筋要素間の腐食電流をマクロセル電流, 鉄筋 要素内の腐食電流をミクロセル電流と定義した。

マクロセル電流の測定概要を Fig. 2 に示す。隣接する 鉄筋要素間に無抵抗電流計を接続し電流（マクロセル電 流）を求めた。次に, 対象とする鉄筋要素の両端から出 入する電流を合計した。この電流を鉄筋要素の表面積で 除することにより, 鉄筋要素表面でのマクロセル電流密 度を算定した。鉄筋要素 $\mathrm{i}$ のマクロセル電流密度 $I_{\text {macro }}$ は 次式で表わせる。

$$
I_{\text {macro }}=\frac{I_{i-1, i}-I_{i, i+1}}{S_{i}}
$$

ここで, $I_{\text {macro }}=$ 鉄筋要素 $i$ のマタロセル電流密度 $\left(\Lambda / \mathrm{cm}^{2}\right), I_{i, j}=$ 鉄筋要素 $i$ と $j$ 間を流れる電流 $(\mathrm{A}), S_{i}=$ 鉄筋要素 $i$ 表面積 $\left(\mathrm{cm}^{2}\right)$ を示す.

そして，対象とする鉄筋要素がアノードの場合，電流 密度は正として表わした。一方，対象とする鉄筋要素が カソードの場合, 電流密度は負として表わした。なお， 腐食電流密度が $100 \mu \mathrm{A} / \mathrm{cm}^{2}$ は, 腐食速度が $1.16 \mathrm{~mm} /$ 年

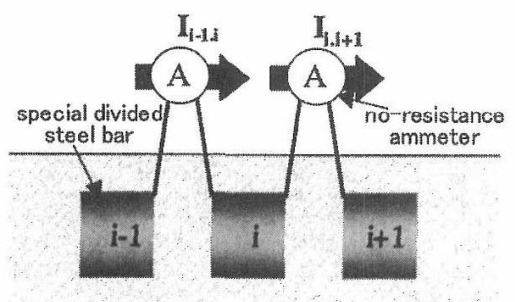

Fig. 2. Measurement of macro-cell current.

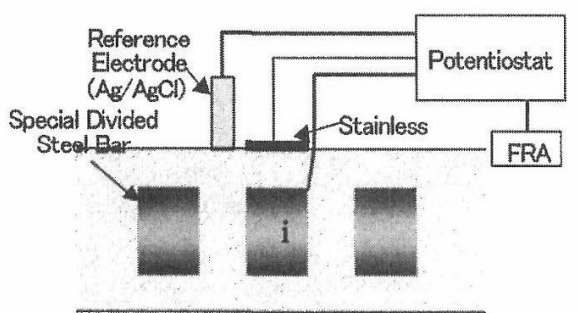

Fig. 3. Measurement of polarization resistance.
に相当する。

次に，ミクロセル電流密度の測定方法を示す。対象と する鉄筋要素のみの分極特性を测定するため，各鉄筋要 素間を接続するリード線を一度切断した。この状態で， 各鉄筋要素每の鉄筋表面の分極抵抗を FRA (Frequency Response Analyzer) 䘮用いた交流インピーダンス法によ り求めた。測定概要を Fig. 3 に示す。測定は, $1000 \mathrm{~Hz}$ から $0.01 \mathrm{~Hz}$ の範囲において，振幅 $50 \mathrm{mV}$ の電圧を与え ることにより行った。また，分極抵抗は，ボード線図括 よびコールコールプロットを用いて算定した。 ミクロセ 儿電流密度 $I_{\text {micro }}$ は文献 5) を参考にして次式により算定 した。

$$
I_{\text {micro }}=\frac{K}{R_{P i}}
$$

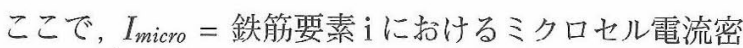
度 $\left(\mathrm{A} / \mathrm{cm}^{2}\right), R_{P i}=$ 鉄筋要素 $\mathrm{i}$ に打ける分極抵抗 $(\Omega$. $\mathrm{cm}^{2}$ ) , $K=$ 定数 (文献 5) を参考にし，0.0209(V)）を示す.

なお，各鉄筋要素間を接続するリード線を切断した状 態で測定した。したがって，対象とする鉄筋要素と他の 鉄筋要素は電気的に接続されておらず，切断前と切断後 の腐食回路，腐食反応の釣り合い状態は異なる。ただし， 分極抵抗とは電気二重層（不動態）の抵抗である。ここ で, 電気二重層 (不動態) の顕著な破塙は，本実験の範 囲では主に二酸化炭素の供給に伴うモルタル中細孔溶液 の $\mathrm{pH}$ 低下により生じる。また，分極抵抗を測定するた めにリード線を切断した時間は1時間以内である。した がって，リード線が切断されている時間中に，二酸化炭 素の供給に伴う $\mathrm{pH}$ 低下により破壤される電気二重層

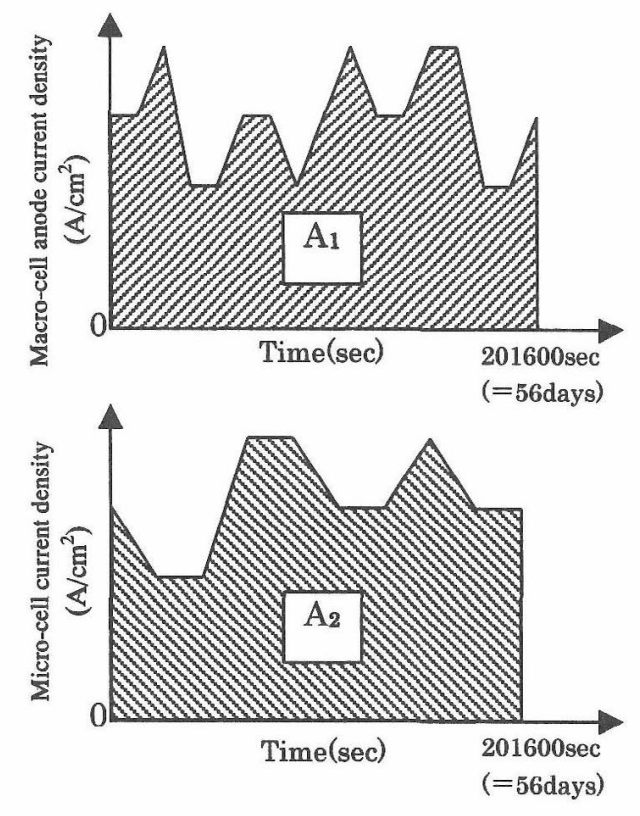

Total Corrosion Electricity Density $\left(\mathrm{C} / \mathrm{cm}^{2}\right)=\mathrm{A}_{1}+\mathrm{A}_{2}$
$\mathrm{~A}_{1}=\int_{0}^{201600}$ Macro-cell anode current density $\left(\mathrm{A} / \mathrm{cm}^{2}\right) \mathrm{dt}$
$\mathrm{A}_{2}=\int_{0}^{201600}$ Micro-cell current density $\left(\mathrm{A} / \mathrm{cm}^{2}\right) \mathrm{dt}$
Where, $\mathrm{A}_{1}$ is Macro-cell electricity density, $\mathrm{A}_{2}$ is Micro-cell
electricity density.

Fig. 4. Definition of total corrosion electricity. 
(不動態) は僅かであると考えられる。このため，木実験 の範囲では，リード線の切断が分極抵抗值に及ぼす影響 は小さいと考えられる。

\section{$2 \cdot 2$ 腐食形態および腐食速度の評価法}

2・2・1 総腐食電気量密度の定義 56 日間の本試験 期間中に流れたマクロセルアノード電流密度とミクロセ ル電流密度を時間積分し, マクロセル電気量密度とミク ロセル電気量密度を求めた。さらに，それぞれを合計し 総腐食電気量密度を算定した。すなわち, 総腐食電気量 密度とは, Fig. 4 に示す面積の和である。

$\mathbf{2} \cdot \mathbf{2} \cdot \mathbf{2}$ 腐食形態の評価 腐食形態に関する評価で は, (1)腐食位置の判定, (2)マクロセル卓越型腐食とミク ロセル卓越型腐食の区別を行った。ここで, 判定基準を 示す。(1)に関しては内部鉄筋の観察（マクロセル電流密 度およびミクロセル電流密度の測定が終了した供試体を 割裂し，内部鉄筋の腐食状態を観察），および測定され た総腐食電気量密度が相対的に高い場所を限定し，アノ ード部と判定した。(2)に関しては, マクロセル電気量密 度とミクロセル電気量密度の最大值を比較した。ここで は明らかに両者に差がみられる場合を卓越型として基準 を設けた。すなわち，「2/3(0.67) ミ(マクロセル電気量 密度/ミクロセル電気量密度)」の時をミクロセル卓越型

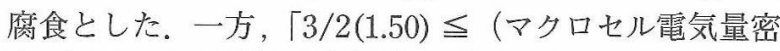
度/ミクロセル電気量密度)」の時をマクロセル卓越型腐

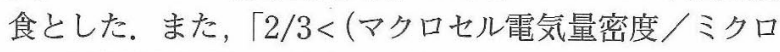
セル電気量密度 $)<3 / 2 」$ の時をマクロセル・ミクロセル 併存型腐食とした。

$2 \cdot 2 \cdot 3$ 腐食速度の評価 腐食速度に関する評価は, 最高総腐食電気量密度の值により判定した。本研究では 宮川らの研究 ${ }^{6)}$ を参考にし, 鉄筋腐食減少量と鉄筋耐力 の関係から 30 年後における鉄筋耐力が，腐食速度の遅 い方では健全時の70\%以上，一方速い方では健全時の $35 \%$ 以下となる腐食減少率を求め, 只の総腐食電気量密 度を逆算した。そして 56 日間の総腐食電気量密度の最 高值が $20 \mathrm{C} / \mathrm{cm}^{2}(0.034 \mathrm{~mm} /$ 年に相当）よりも低い場合 を腐食速度が遅い， $50 \mathrm{C} / \mathrm{cm}^{2}(0.085 \mathrm{~mm} /$ 年に相当）よ りも高い場合は腐食速度が速いと判定した。なお，部材 の寿命を健全時の耐力の 70\%に低下するまでの期間と定 義した時, 腐食速度の遅い場合の寿命は 30 年以上, 速

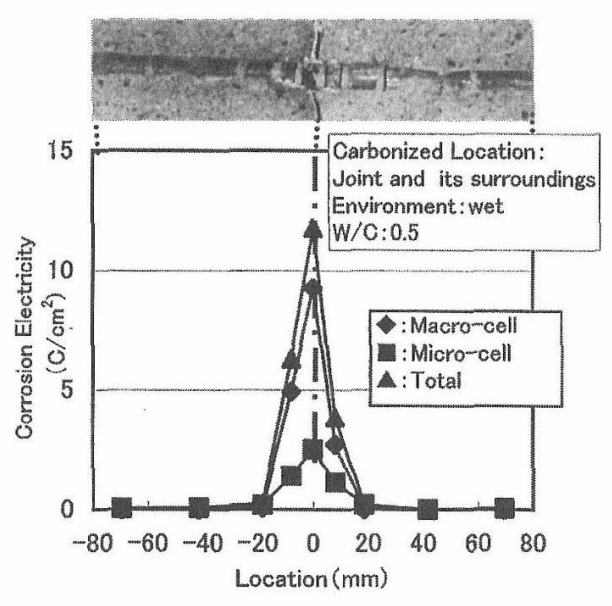

Fig. 5. Example of corrosion electricity distributions along a reinforcement.
い場合の寿命は 15 年以内である。

$2 \cdot 2 \cdot 4$ 腐食形態と腐食速度の測定例 Fig. 5 に測 定例を示す。これは, 中性化位置が久陷部と近傍, 外部 環境が湿潤，水セメント比が 0.5 の場合における鉄筋の 腐食状態之腐食電気量密度分布である。

鉄筋の観察結果によれば，欠陥部およびその近傍にお いて錆びていることが認められる。また, 総腐食電気量 密度は欠䧗部とその近傍で高くなっていることが認めら れる。(マクロセル電気量密度／ミクロセル電気量密度)

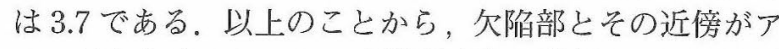
ノードとなるマクロセル卓越型腐食が進行していると判 断できる。

また, 最高総腐食電気量密度は $11.79 \mathrm{C} / \mathrm{cm}^{2}$ である。 したがって，腐食速度は遅いと判断できる。

\section{2・3 腐食形態および腐食速度の整理}

2・3・1 腐食形態 Fig. 6 に腐食形態をまとめる。 上段・中段・下段はそれぞれ水セメント比が $0.3 \cdot 0.5$ ・ 0.7 の結果である. 各段の横軸は, 外部噮境すなわち水 分および酸素の供給条件を示す。縦軸は, 二酸化炭素の 供給条件を示す. また, 各楕円内の文字はアノード位置 を示す。塗りつぶしはミクロセル卓越型腐食, ドット付 きはマクロセル・ミクロセル併存型腐食, 白始はマク ロセル卓越型腐食を示す。

これによると, 中性化位置が欠陥部またはその近傍の 場合には，艺の箇所が腐食することが認められた。ただ し, 水セメント比が 0.3 , 中性化位置が久陷部のみの場 合には, 外部環境が乾燥あるいは湿潤の時に腐食の発生 が認められなかった。これは，欠陷部が中性化した場合， その部分に扔いては不動態皮膜の破缞が促進される。し かしながら, 水セメント比が低いため, 乾燥状態では水 分の供給が, 湿潤環境では酸素の供給が不足するため, 腐食の進行は困難で西ったと考えられる。

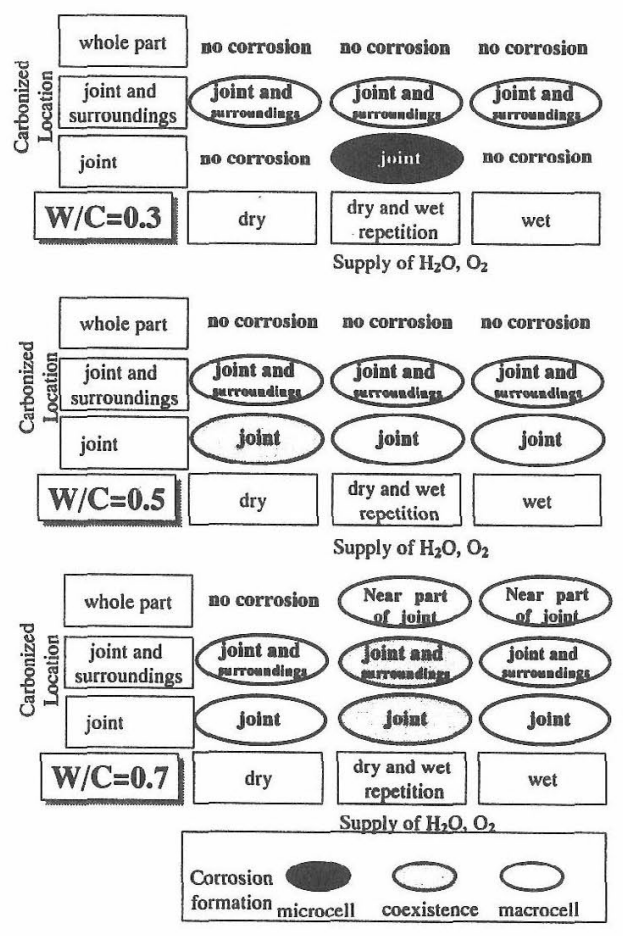

Fig. 6. Corrosion cell formation pattern and the location. 
また，中性化位置が全体の場合，水セメント比が 0.7 の時には，アノード位置に関する定まった傾向は見られ ないことが認められた。これは，全体が中性化した場合 には鉄筋全体の不動態が破壇される可能性はある。ただ し，酸素と水分の供給条件によってアノード部の位置は 変化するため，アノード部の定まった傾向は認められな かったと考えられる。な打，水セメント比が 0.3 や 0.50 場合には，水分，酸素が十分に供給されないため腐食は 進行しなかったと思われる。

さらに，全体的にマクロセル腐食が卓越する傾向が認 められる。これは，中性化したモルタルでは，水酸化力 ルシウムが炭酸カルシウムに変化しセメントペーストが 緻密化され，細孔量が減少する? このため中性化の進行 に伴い，欠陷部以外（欠陥の影響を受けないモルタル内 部）では腐食要因である物質の供給が困難になる。その 結果，欠陷部とそれ以外のモルタル部分において，内部 鉄筋への酸素供給量の差が大きくなる。Table VIに，欠 陥部とそれ以外のモルタル内部に位置する内部鉄筋への 酸素供給量の比を示す。また，モルタル内部に位置する 鉄筋への酸素供給量も示す。ここで，Fig. 7 を用いて酸 素供給量の測定方法を記す. No.4〜 No.6 供試体に打い て対象とする鉄筋要素とステンレス問にポテンショスタ ットを接続し, 鉄筋を陰極, ステンレスを陽極として, $860 \mathrm{mV}$ の電位差を設けた。 ${ }^{8)} こ の$ 電位差は，予め同様の供 試体のカソード分極曲線を測定し，限界電流密度となる 電位であることを確認した。光して，定常状態における 電流を測定し，モルタル内部を通過し鉄筋表面での力ソ 一ド反応に扔いて消費される酸素量を次式から算定した。

$$
\frac{d Q}{d t}=\frac{i_{\text {lim }}}{n F}
$$

ここで, $d Q / d t=$ 単位時間あたりの任意の鉄筋要素へ の酸素供給量 $\left(\mathrm{mol} / \mathrm{cm}^{2} \mathrm{sec}\right), i_{\text {lim }}=$ 限界電流密度 $\left(\mathrm{A} / \mathrm{cm}^{2}\right), n=$ カソード反応に扔いて $1 \mathrm{~mol}$ の酸素分子と 反応する電子数 $(n=4), F=$ ファラデー定数 $(=96500 \mathrm{c} /$ mol) を示す.

以上の測定により求めた値を用い，欠陷部とそれ以外 のモルタル内部に位置する内部鉄筋への酸素供給量の比 を算定した。したがって，この值が大きいほど，沿部

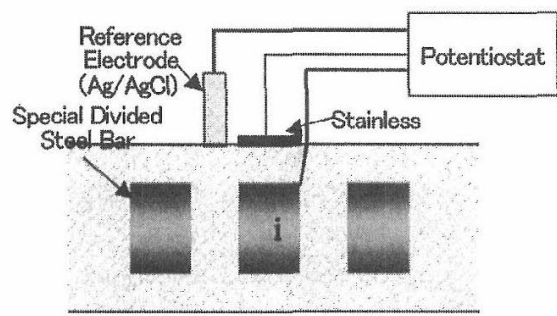

Fig. 7. Measurement of oxygen permeability.
の鉄笴への酸素供給量が，モルタル内部の鉄筋への酸素 供給量と比較して，相対的に多量になることを意味する。 Table VIによると，中性化の影響を受けた供試体では， 欠陌部とそれ以外のモルタル内部に位置する鉄筋への酸 素供給量の比が大きくなることが確認できる。すなわち， 中性化の影響を受けた供試体では，欠陷部とそれ以外の モルタル内部に位置する鉄筋への腐食要因物質の供給量 の偏りが大きくなる。このため，マクロセルが形成され やすくなると考えられる。

2・3・2 腐食速度 Fig. 8 に腐食速度の判定結果を まとめる。各段の横軸, 縱軸はFig. 6 と同様である。 ま た，楕円内の值は最高総腐食電気量密度を示す。

これによれば，全体的に水セメント比が低いほど腐食 速度が遅いことが認められる。これは，水セメント比が 低いほど，物質供給量が減少するためと考えられる。

$2 \cdot 4$ まとめ

本章では，モルタル試験により腐食形態と腐食速度を 統一した条件でかつ網濰的に整理した。得られた結論を 以下にまとめる。

（1）腐食形態を整理した結果，水セメント比に拘わら ず，マクロセル卓越型腐食が進行する傾向にあることが 明らかとなった。

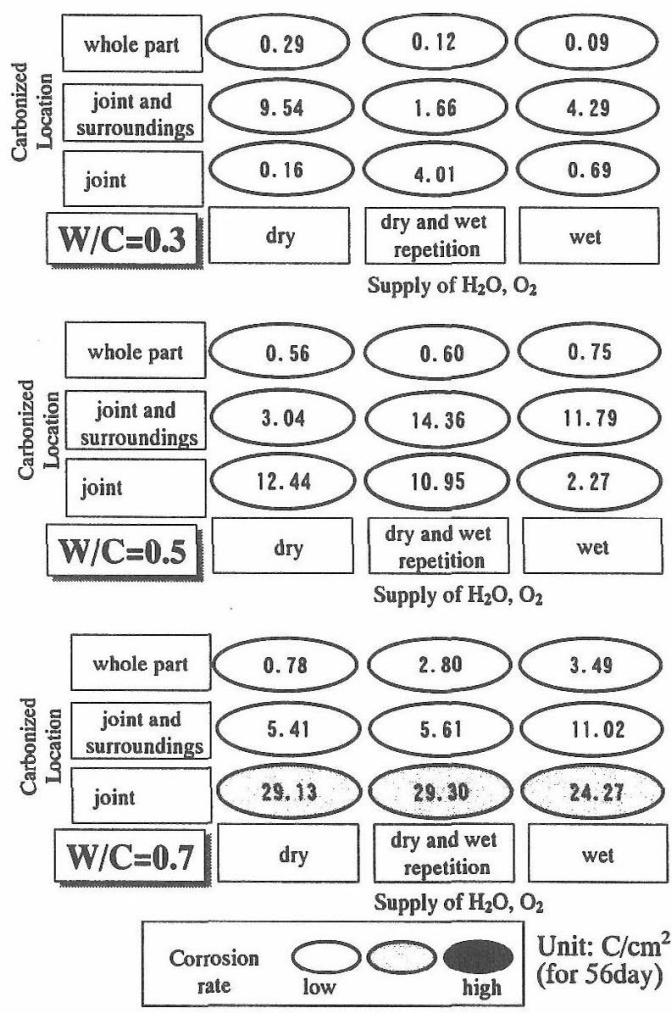

Fig. 8. Corrosion rate.

Table VI. Ratio between oxygen supply quantity to the steel across the joint and in mortar.

\begin{tabular}{|c|c|c|c|c|}
\hline & No- Carbonation & \multicolumn{3}{|c|}{ Carbonation } \\
\hline W/C & 0.5 & 0.3 & 0.5 & 0.7 \\
\hline $\begin{array}{c}\text { Oxygen supply quantity to the steel through the joint } \\
\text { per unit area (mol/cm } / \mathrm{sec})\end{array}$ & 4.6 & 65.6 & 23.6 & 6.0 \\
\hline $\begin{array}{c}\text { Oxygen supply quantity to the steel in mortar } \\
\left.\text { per unit area (mol/ } \mathrm{cm}^{2} / \mathrm{sec}\right)\end{array}$ & 3.35 & 0.09 & 0.30 & 0.50 \\
\hline $\begin{array}{c}\text { Oxygen supply quantity to the steel in mortar } \\
\text { per unit area }\left(10^{11} \mathrm{~mol} / \mathrm{cm}^{2} / \mathrm{sec}\right)\end{array}$ & & & & \\
\hline
\end{tabular}


（2）腐食速度を整理した結果，水セメント比が低いほ ど腐食速度は遅くなることが明らかとなった。

\section{$3 \cdot 1$ 実験概要}

$$
3 \text { コンクリート試験 }
$$

$3 \cdot 1 \cdot 1$ 使用材料 セメント，細骨材および高性能 $\mathrm{AE}$ 減水剤は $2 \cdot 1 \cdot 1$ 項で示した材料と同じである。粗 骨材は東京都奥多摩産の砕石を使用した。粗骨材の主な 物理的性質を, Table VII示す。また，水セメント比が 0.5 および 0.7 のコンタリートに対し, ナフタレン系減水 戍およびAE 刜を使用した。

3・1・2 実験ケース 実験ケースをTable 泪に示す。 コールドジョイント部に生じる腐食を対象とした検討, および曲げひび割れ部に生じる腐食を対象とした検討を 行なった. 水セメント比は $0.3,0.5,0.7$ の 3 通りとし た。なお，コンクリートの配合を Table IXに示す。

$3 \cdot 1 \cdot 3$ 供試体概要 はじめに, コールドジョイン ト部を模擬した供試体の概要を Fig. 9 に示す。埋設した 鉄箭は 12 本に分割した。鉄筋の前処理は，モルタル供 試体と同椂である。前処理が終了した鉄筋をかぶりが $3 \mathrm{~cm}$ になる位置に設置し, 高さ $150 \mathrm{~cm}$ まで打設した. 18 時開後にワイヤブラシでレイタンスを除去し, 打継ぎを 行なった。打設後, 相対湿度 $80 \%$ 室温 $20^{\circ} \mathrm{C}$ に湿空養

Table VII. Physical property of coarse aggregate.

\begin{tabular}{|c|c|}
\hline Density $\left(\mathrm{g} / \mathrm{cm}^{3}\right)$ & 2.64 \\
\hline $\begin{array}{c}\text { Coefficient of water } \\
\text { absorption }(\%)\end{array}$ & 0.68 \\
\hline Fineness Modulus & 6.70 \\
\hline Max grain size $(\mathrm{mm})$ & 20 \\
\hline
\end{tabular}

Table VIII. The experiment cases (concrete tests).

\begin{tabular}{|c|c|c|}
\multicolumn{3}{|c|}{ (a)Cold joint } \\
\begin{tabular}{|c|c|c|}
\hline \multicolumn{3}{|c|}{ W/C } \\
\hline 0.3 & 0.5 & 0.7 \\
\hline & 0 & 0 \\
\hline
\end{tabular}
\end{tabular}

(b)Bending crack
\begin{tabular}{|c|c|c|}
\hline \multicolumn{3}{|c|}{ W/C } \\
\hline 0.3 & 0.5 & 0.7 \\
\hline & 0 & \\
\hline
\end{tabular}

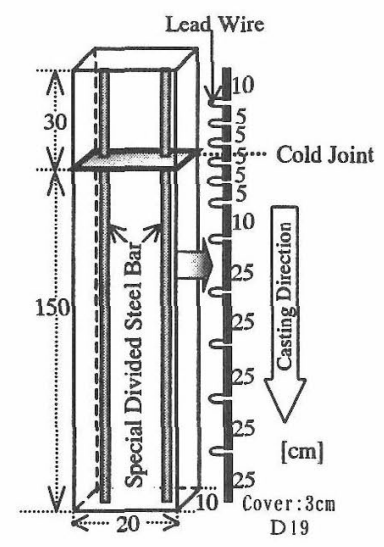

Fig. 9. Configuration of specimen with cold joint.
生を行った。材齢 28 日目において，上面および下面を エポキシ樹脂により被覆し，二酸化炭素，水分および酸 素が端部から浸透することを防いだ。それから，中性化 促進環境下 (二酸化炭素濃度 $10 \%$, 温度 $40^{\circ} \mathrm{C}$, 湿度 $70 \%$ ) に2ケ月間暴露した。

次に，曲げひび割れ部を模擬した供試体の概要を Fig. 10 に示す。埋設した鉄筋は 7 本に分割した。鉄筋の前処 理は，モルタル供試体と同様である。前処理が終了した 鉄筋は，曲げ載荷時にリード線の付いた面が圧縮側とな るよう,リード線の付いた面を上側にして型枠に設置し た。なお，全面にエポキシ樹脂を被覆した曲げ補強鉄筋 を，分割鉄筋と並列に埋設した。打設後，相対湿度 $80 \%$ 室温 $20^{\circ} \mathrm{C}$ に湿空養生を行った。材齢 28 日目において, 供試体下面の中央部に曲げひび割れを設けた。曲げひび 割れは，Fig. 11 に示すように 3 点曲げ載荷により生じ させた。マイクロスコープを用いひび割れ開口部を覾察 し，ひび割れ幅が $0.3 \mathrm{~mm}$ に達した時点で載荷を終了し， 厚さが $0.1 \mathrm{~mm}$ ，幅が $5 \mathrm{~mm}$ のステンレス板をひび割れ開 口端部に挟み，曲げひび割れ幅を $0.3 \mathrm{~mm} に$ に制御した (Fig. 10 参照)。なお，このように曲げ載荷によりひび割 れを導入することにより，曲げひび割机近傍に生じる鉄 筋とコンクリートのはく離 ${ }^{4)}$ を考慮できた.9 また, ひび 割れ開口面を除く 5 面を，エポキシ樹脂により被覆し， 二酸化炭素, 水分およひ酸素の供給が 1 面の及から生じ

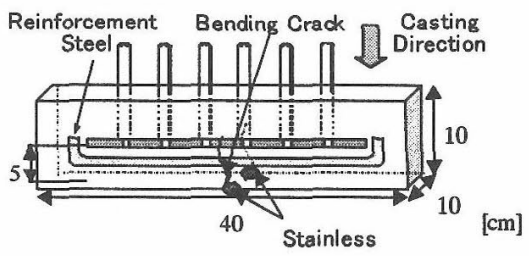

(1) Specimen

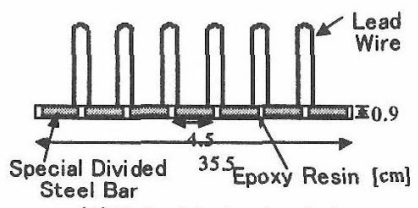

(2) Embedded steel bar

Fig. 10. Configuration of specimen with bending crack.

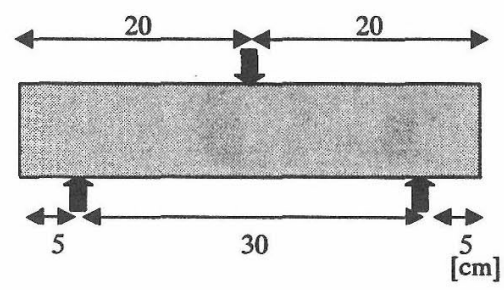

Fig. 11. Bending method.

Table IX. Mixture proportion of concrete.

\begin{tabular}{|c|c|c|c|c|c|c|c|c|c|}
\hline \multirow{2}{*}{$\mathrm{W} / \mathrm{C}$} & \multirow{2}{*}{$\begin{array}{l}/ a \\
(\%)\end{array}$} & \multicolumn{4}{|c|}{ Unit weight $\left(\mathrm{kg} / \mathrm{m}^{3}\right)$} & \multicolumn{3}{|c|}{ Agent $\left(\mathrm{g} / \mathrm{m}^{3}\right)$} & \multirow{2}{*}{$\begin{array}{c}\text { Compressive } \\
\text { strength }{ }^{*}(\mathrm{MPa})\end{array}$} \\
\hline & & $\bar{W}$ & $\mathrm{C}$ & $\mathrm{S}$ & $\mathrm{G}$ & $\mathrm{A}$ & $\bar{B}$ & $\mathrm{C}$ & \\
\hline 0.3 & 39 & 165 & 550 & 600 & 963 & 6875 & - & - & 73 \\
\hline 0.5 & 45 & 165 & 330 & 803 & 989 & - & 743 & 13.2 & 45 \\
\hline 0.7 & 45 & 165 & 236 & 837 & 1032 & - & 637 & 9.4 & 28 \\
\hline
\end{tabular}

Note) A : superplasticizer, B : water reducing agent, C : Air entraining agent $\% 28$ day 
るようにした, その後, 中性化促進環境卜 (二酸化炭素 濃度 $10 \%$, 温度 $40^{\circ} \mathrm{C}$, 湿度 $70 \%$ ）に3 ケ月間暴露した。

$3 \cdot 1 \cdot 4$ 測定方法 マクロセル電流密度扎よびミク ロセル電流密度を测定した。測定方法は, モルタル試験 と同様である。

\section{$3 \cdot 2$ コールドジョイント部に生じる腐食の形態と速度}

3・2・1 実験結果 Fig. 12 に, マクロセル電流密

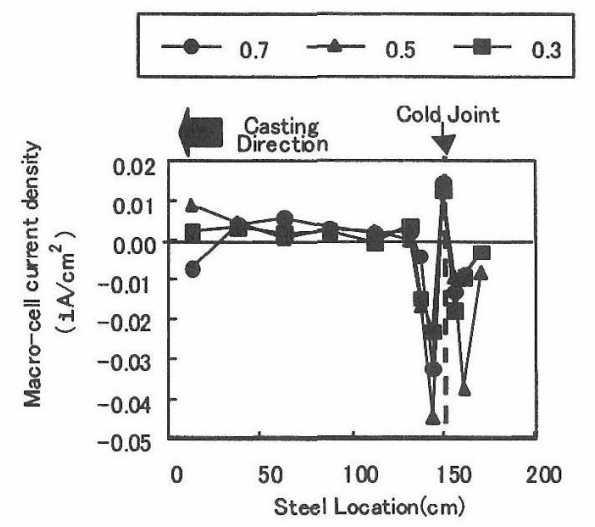

(1)Macro-cell current density

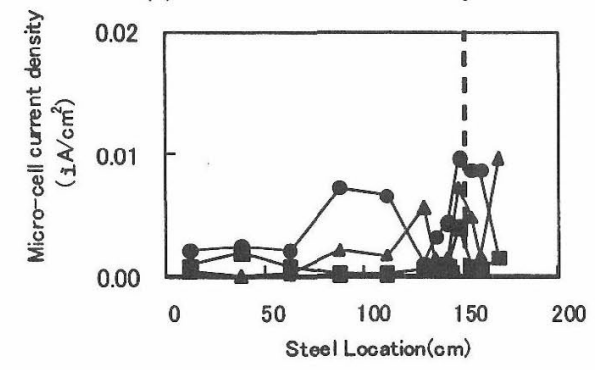

(2)Micro-cell current density

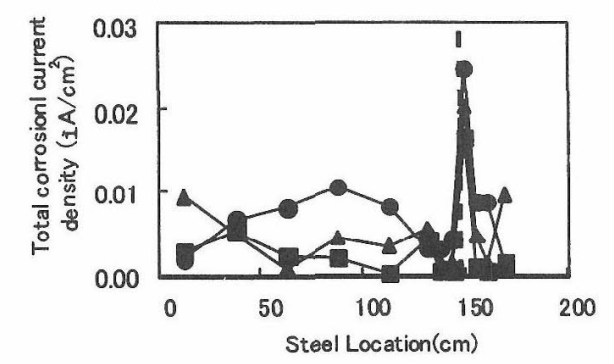

(3)Total corrosion current density

Fig. 12. Distribution of corrosion current density in concrete with cold joint.
度, ミクロセル電流密度および総腐食電流密度を示す。 水セメント比が 0.3 の場合, マクロセル電流密度, ミク ロセル電流密度および総腐食電流密度は, いずれも低い。 水セメント比が 0.5 の場合, マクロセル電流密度, ミタ ロセル電流密度および総腐食電流密度は, コールドジョ イント位置において高くなる。水セメント比が 0.7 の場 合, マクロセル電流密度, ミクロセル電流密度および総 腐食電流密度は, コールドジョイント位置において高く なる。

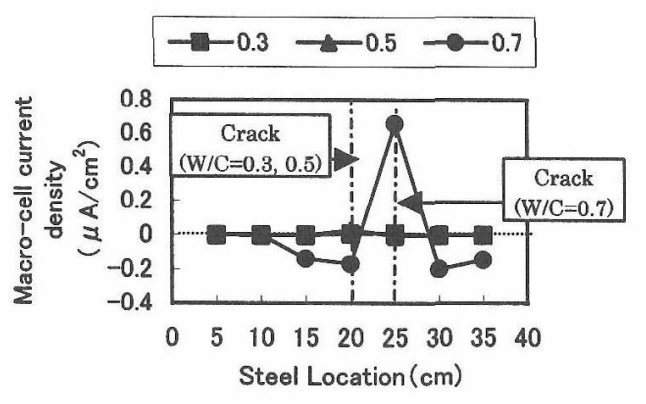

(1)Macro-cell current density

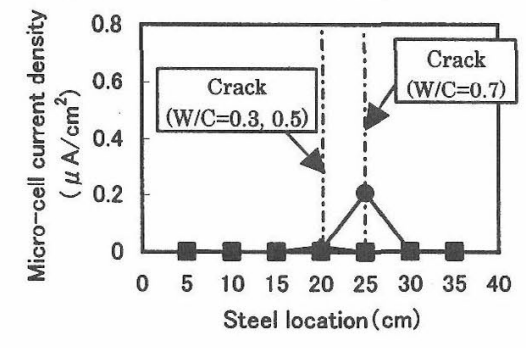

(2)Micro-cell current density

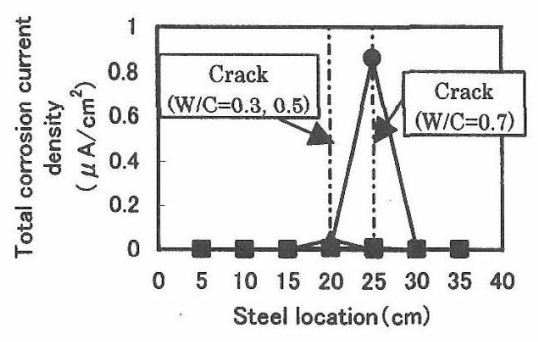

(3)Total corrosion current density

Fig. 14. Distribution of corrosion current density in concrete with bending crack.

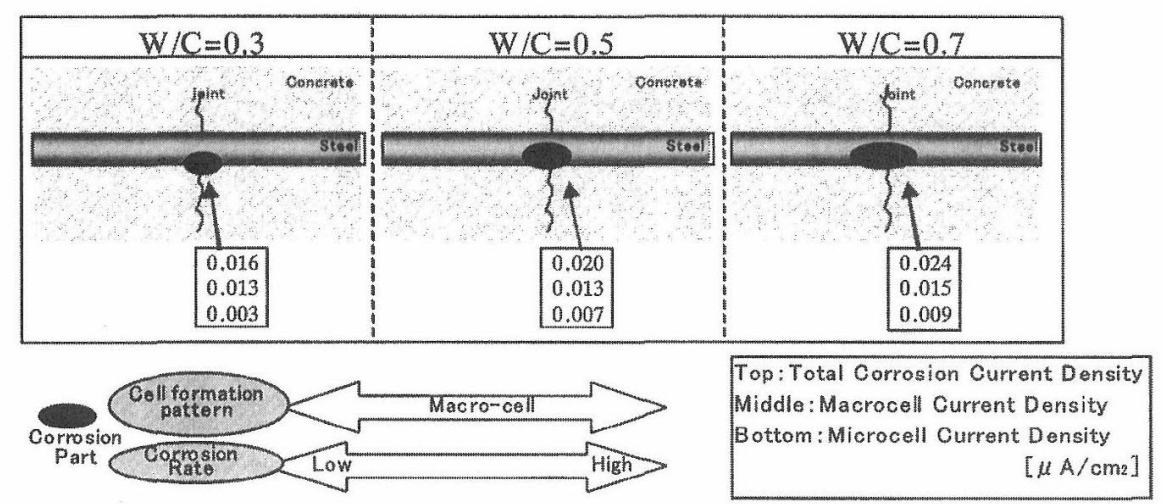

Fig. 13. Corrosion cell formation pattern and corrosion rate in concrete with cold joint. 
3・2・2 腐食形態と腐食速度の整理 Fig. 13 に， マ クロセルのアノード部となったコールドショイント位置 に扮ける腐食速度を示す。はじめに，腐食形態について 整理する。Fig. 13 によれば，水セメント比に拘わらず, マクロセル電流密度はミクロ七儿電流密度と比較して高 いことが認められる。すなわち, 何机の水セメント比に おいてもマクロセル卓越型腐食が進行することが認めら れる。この傾向は, モルタル試験の結果と同様である。 次に，腐食速度について整理する。Fig. 13 によれば， 水セメント比が高いほど，腐食速度は速くなることが確認 できる。この傾向は，モルタル試験の結果と同様である.

\section{3 ・3 曲げひび割れ部に生じる腐食の形態と速度}

$3 \cdot 3 \cdot 1$ 実験結果 Fig. 14に, マクロセ儿電流密 度, ミクロセル電流密度および総腐食電流密度を示す。 水セメント比が 0.3 の場合, マクロセル電流密度, ミク ロセル電流密度および総腐食電流密度は，いずれも低い。 水セメント比が 0.5 の場合, マクロセル電流密度, ミク 口セル電流密度および総腐食電流密度は，ひび割れ位置 に打いて高くなる。水セメント比が 0.7 の場合，マクロ セル電流密度, ミクロセ儿電流密度および総腐食電流密 度は，ひび割れ位置において高くなる。

$3 \cdot 3 \cdot 2$ 腐食形態と腐食速度の整理 Fig. 15 に, マ クロセルのアノード部となった曲げひび割れ位置に拈け る腐食速度を示す。はじめに，腐食形態について整理す る.Fig. 15 によれば，水セメント比に拘わらず，マクロ セル電流密度はミクロセル電流密度と比較して高いこと が認められる。すなわち，何れの水セメント比において もマクロセル卓越型腐食が進行することが認められる。 この傾向は，モルタル試験の結果と同様である。次に， 腐食速度について整理する。Fig. 15 によ机ば，水セx ント比が高いほど，腐食速度は速くなることが確認でき る。この傾向は，モルタル試験の結果と同様である。

\section{4 結 論}

本研究では，欠陷を有する鉄筋コンクリート部材に生 じる中性化に伴う腐食の形態と速度に関して, 整理なら びに比較を行った。以下に本研究の結論を示す。
（1）中性化位置，水分打よひ酸素の供給条件，モル夕 ルの水セメント比に相違を設け，全27ケースの腐食形 態と腐食速度を, 統一しした条件のもと網羅的に整理・比 較できた。

（2）准がある場合，中性化による腐食は，水セメン 卜比に拘わらずマクロセル卓越型腐食が進行する傾向に ある。また, 水セメント比が低いほど, 腐食速度は遅く なる。

（3）上記 2 の結果は，モデル欠陥部を対象としたモル タル試験のみならず, コールドジョイント部および曲げひ び割れ部を対象としたコンクリート試験でも確認された。

（4）以上の結果を踏まえると，中性化の影響を受ける 環境では，欠陥がある場合においても，水セメント比が 低いことが腐食に対する耐久性に優れていると言える。

本研究をまとめるに当たり，東京工業大学大学院材料 工学専攻教授水流徹先生のご指導を賜った。ここに感謝 の意を表する。

\section{参 考 文 献}

1) 北後征雄, 宮川豊章, 材料, 49, 413 (2000).

2）佐伯竜彦, 大即信明, 長淁重義, 土木学会論文集, No.532, 55 (1996).

3) J. A. Gonzalez, S. Algaba and C. Andrade, British Corrosion Journal, 15[3], 134 (1980).

4）神山一，セメント技術年報，26，491（1972）。

5 ) 水流徹, 前田 龍, 春川志郎, 防食技術。 28,638 (1979).

6) 宮川豊章, 武若耕司, 出村克宣, 桝田佳寛, 守分敦郎, コンクリート工学年次論文報告集，20 [1]，43（1998）。

7) 佐伯竜彦, 米山絃一, 長滝重義, 土学会論文集, No.451, 69 (1992).

8）木内芳夫, 宫川豊章, 岡田 清, 第 38 回土木学会年次学 術講演会講演概要集, V，265(1983).

9) 大即信明, 宮里心一, 柴田常徳, 久田 真, Md. Tarek Uddin，長㴰重義，土木学会論文集，No.606，63 (1998).

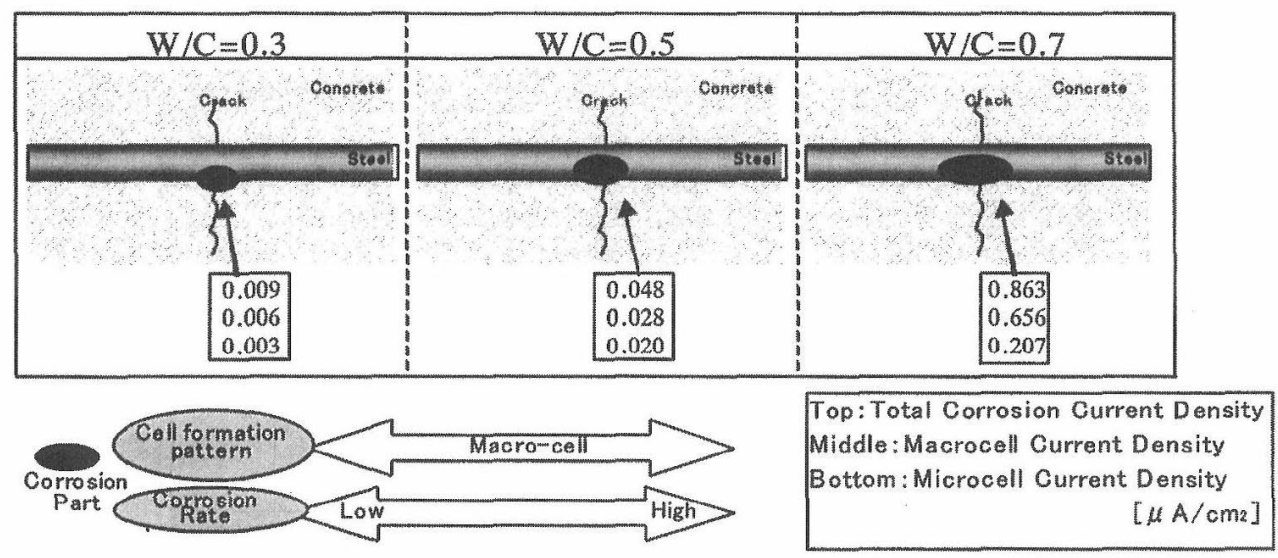

Fig. 15. Corrosion cell formation pattern and corrosion rate in concrete with bending crack. 